\title{
Distressing Near-Death Experiences as Photographic Negatives
}

\author{
Gracia Fay Ellwood, M.A. \\ California State University, Long Beach
}

ABSTRACT: This essay presents various interpretative frameworks for painful near-death experiences (NDEs). It describes Bruce Greyson and Nancy Evans Bush's three-part typology of inverted NDEs, everlasting void experiences, and hellish experiences, suggesting a further breakdown of the latter into entity-centered and fire-centered. A potential fourth category is the empathetic life review. As a religious context for distressing experiences, I present Rudolf Otto's concept of the nonrational mysterium tremendum. The major rational paradigms that have been applied to such experiences can be categorized as the supernaturalistic, the reductionistic, and the one-world types. I give examples of several kinds of one-world views, particularly three Christian mystics of early modern times, and offer suggestions of ways in which elements of different one-world views might be combined.

The [D]ove descending breaks the air

With flame of incandescent terror. . . .

Who then devised the torment? Love.

... We only live, only suspire

Consumed by either fire or fure.

T. S. Eliot, "Little Gidding," 1952, pp. 143-144

O dark dark dark. They all go into the dark,

The vacant interstellar spaces, the vacant into the vacant. . . .

We must be still and still moving

Into another intensity

For a further union, a deeper communion

Through the dark cold and the empty desolation. . . .

In my end is my beginning.

T. S. Eliot, “East Coker," 1952, p. 126

Gracia Fay Ellwood, M.A., is in the Department of Religious Studies at California State University, Long Beach. Reprint requests should be addressed to Ms. Ellwood at The Cypresses, 997 Athens Street, Altadena, CA 91001. 
For most of the 21 years since Raymond Moody's Life After Life (1975) opened the field of near-death studies on both popular and academic levels, the focus has been on radiant experiences. However, as early as 1978, Maurice Rawlings' Beyond Death's Door spoke emphatically of the existence of distressing experiences as well; Charles Garfield reported in 1979 that half of his dying cancer patients had distressing experiences. Besides the work of these early researchers, occasional isolated cases were published.

At that, Beyond Death's Door (Rawlings, 1978) was not the first book to deal with distressing near-death experiences (NDEs). Glimpses of the Beyond, by Jean-Baptiste Delacour, which appeared in the United States in 1974, a translation of Aus dem Jenseits Zurück (1973), recounted a variety of purportedly real NDEs that included hellfire and desolation scenes. The author clearly was familiar with near-death data, but his book showed signs of plagiarism and fictionalization, which left the reader unwilling to trust to the accuracy of the cases.

Garfield has not published any of his stories at all, so far as I know, making them eminently easy to disregard. Rawlings, on the other hand, recounted several stories of burning impact. But for some years, comparatively little notice was taken in mainline near-death studies. The basic reasons are not far to seek: the cases are disagreeable, and they appeared as part of a fundamentalist package that refused critical analysis. Besides, as Bruce Greyson (1990) and Nancy Evans Bush (1993) have pointed out, those who have had frightening NDEs tend to be as reluctant to tell them as investigators have been to ask. But as the 1980 s progressed, the existence of distressing cases was acknowledged in several significant works, and alternative interpretations considered.

\section{Types of Distressing NDEs}

Especially important among recent studies is Greyson and Bush's essay "Distressing Near-Death Experiences" published in Psychiatry in 1992. Greyson and Bush presented a typology of three major kinds of distressing NDEs.

\section{Inverted NDEs}

The first type has essentially the same format as the tunnel-andlight blissful NDE, but is perceived by the experiencer as frightening 
instead. Kenneth Ring referred to these with the apt term "inverted NDEs" (Ring, 1994). This kind is sometimes related to rigidity of ego boundaries with fear of loss of control, as evidenced by the change to a peaceful experience in some cases when the NDEr lets go and accepts the experience. Though much more can be said about this type, in what follows I will focus on the second and third types, which at first view pose greater difficulties, before suggesting a potential fourth type.

\section{Everlasting Void Experiences}

In the second kind, the experiencer finds her- or himself in a featureless dark void in utter loneliness. In some cases the message is given that all of life is a product of one's imagination, a cruel joke the experiencer was allowed to believe to be real. In any case, all contact with the world is seen to be permanently cut off, and the psychological pain is unutterable.

An example is the mystical experience of NDEr Peggy Holladay. She came close to death in an auto accident in 1974, and though she did not remember a narrative NDE, NDE-type images emerged into her consciousness afterwards. Thirteen years later, and four months after a major mystical encounter with the light, she was looking into a mirror one morning and asking herself, "What am I really upset about?"

Suddenly she found herself on the other side of the mirror, being dragged by some incredibly powerful magnetic force into a kind of gray outer space. She was hit (her term) by a conviction that she had died and was "completely ALONE, never to be with any loved ones, .. . no living thing again in any form." The distress was so extreme that it was as though she was feeling all the pain and fear of every living creature that had ever existed. She screamed "No, no!" and tried desperately to get back into her body, which she could still see standing on the other side of the mirror. She finally succeeded in doing so, though for several hours she felt in danger of floating up into space again (P. Holladay, personal communication). Some persons who have void experiences do in fact communicate with entities of some sort, but the sense of emptiness and aloneness may still be there (Greyson and Bush, 1992).

Holladay did not accept the fundamentalist interpretation, which she saw as harmful. Since she had already encountered the light, 
which for her was and is unmistakeably ultimate, she saw this painful experience as having a healing and transforming purpose. But for NDErs who have known only this kind of experience, it may leave feelings of despair and increased, rather than decreased, fear of death.

It may be significant that Holladay saw both her mirror experience and her mystical experience of the light as a return to conscious awareness of what had transpired during her brush with death 13 years before. Of this I will say more later.

\section{Hellish Experiences}

The third kind of case includes imagery of demons and/or hell. The experiencer feels victimized by malevolent entities wanting to drag her or him down into hell, or goes down into a pit, sees or hears the sufferings of tortured beings. There is often a pervading sense of evil that awakens great fear in the experiencer (Greyson and Bush, 1992). An example may be given from the writings of the 8th-century scholar Bede, cited in Carol Zaleski's Otherworld Journeys (1987). The NDEr, a pious Anglo-Saxon householder named Drythelm, succumbed to a severe illness and was met by a shining messenger who escorted him to a huge valley, one side aflame while the other side underwent a hailstorm. Countless souls were tossed back and forth between these torments. The guide explained that this was a place of temporary sufferings and that the souls therein could be released from these punishments by masses and prayers on the part of the living.

The guide then led Drythelm to hell through a land of darkness total except for the guide's light. Hell was a bottomless abyss, stinking and flaming. Damned souls were cast upward on the flames to fall back again amid the sounds of jeering laughter and grief. Malignant spirits dragged three souls into the abyss, and menaced Drythelm, but his guide rescued him.

After this Drythelm was led to a realm of light and joy, which included a walled paradisiacal meadow inhabited by many happy people, and approached heaven, which was similar and more wonderful still. However, despite his wish to remain, he was sent back. The aftermath of his experience was an exchange of his lifestyle for one of monastic austerity. Drythelm told his story to a monk, who 
told it to Bede (Zaleski, 1987); it is, then, a thirdhand account, perhaps not totally accurate, but not the stuff of legend either.

This experience reflects cultural ideas of its period-afterdeath punishment in the form of purgatory and hell, demons, paradise, the authoritative spiritual leader, ideals of asceticism-yet it also bears unmistakeable similarities to certain elements in 20th century experiences such as those of George Ritchie and Howard Storm. Ritchie's experience is familiar to many from his books Return From Tomorrow (Ritchie and Sherrill, 1978) and My Life After Dying (Ritchie, 1991), but I will summarize it for the benefit of those who have not yet encountered them.

Ritchie collapsed of pneumonia and was given up as dead while in military basic training in Texas in December, 1943. After a disembodied flight in the direction of his home state of Virginia, he returned to the scene of his body and had a vision of the light and of Christ. The figure of Christ led him to a series of earthly scenes in which he perceived various earthbound spirits trying unsuccessfully to interact with the living and to satisfy cravings for addictive substances. He also saw a dark area in which many spirits fought with one another or tried to satisfy distorted sexual cravings. All these beings were overshadowed by angelic figures who tried patiently to draw their attention to better things. Ritchie was also guided to a peaceful university-like setting, and saw but did not enter a celestial city before he was induced to return to his body.

Storm's experience was told in some detail in Judith Cressey's The Near-Death Experience: Mysticism or Madness (1994). After suffering prolonged agony from a perforated duodenum, Storm succumbed and was astonished to find himself standing by his bedside looking at his body. His wife and roommate failed to respond to him, and he reacted with anger. Then he was enticed by seemingly helpful entities through a doorway onto a darkening plain where they eventually attacked him savagely. They finally backed off protesting when, in response to the urging of an inner voice, he tried to pray. After a period of intense desolation (the void experience?), again in response to his own voice within, he called to Jesus for help and was rescued by a starlike angelic figure who surrounded him with love, took him among other loving beings, and taught him extensively (Storm, 1989). In these, as in the case of Drythelm, we note the journey through dark realms, angelic compassion for those suffering after death, violent entities, the power of prayer, the rescuing guide, light piercing the darkness, and scenes of pain giving way to scenes of bliss. 


\section{Entity-Centered vs. Fire-Centered Hellish Experiences}

Drythelm's case presented both malicious entities and hellfire, as do some contemporary cases, thus seeming a particularly apt example of the hellish category. However, there are also cases such as Ritchie's and Storm's involving entities but no fire, and I propose that they be considered a separate subcategory, because some entities show distinct analogies to figures in certain more familiar situations, namely schizophrenia and nightmares. Rarely, they also intrude into radiant NDEs, as at the end of Betty Eadie's experience (Eadie and Taylor, 1992).

One source supporting such a connection is The Presence of Other Worlds by clinical psychologist Wilson Van Dusen (1974). In it he distilled the results of 16 years' investigation into the visionary (I avoid the word hallucinatory) figures perceived by schizophrenic patients. Taking the voices seriously and in many cases interviewing them through the patients, he found pervasive similarities among the entities. The majority, which he called "the lower order," manifested lies, inflated claims, threats, perseveration, malice, lack of distinct personal identities, masquerading, obsessions, and perverted sexuality; and all the lower order showed hostility toward anything to do with religion. About one-fifth of the visionary figures were, by contrast, loving and supportive, and offered profound symbolic wisdom (Van Dusen, 1974). I suggest this analogy not to dismiss these NDEs as incidents of psychosis, which they clearly are not, but to prepare the ground for paradigms that will relate these and other classes of experience.

As has been pointed out in the case of radiant NDEs, distressing NDE-like experiences also take place at times when there is no question of nearness to death. Persons in waking consciousness and normal health have experienced malevolent otherworldly entities. In one of the few contemporary cases I know, the experiencer, Gary Wells, was going through a period of psychological and spiritual distress. While alone at work during a night shift he appealed to God "... if you do exist, please let me know." In response he felt a powerful divine presence that gave him a strong sense of his own uncleanness, and commanded him to be holy. This command he resisted. An excruciating headache followed, then a sudden experience of blackness and "a dank, unearthly smell. " He heard voices of two men abusing one another in 
phony, foul language. There were more voices inside the blackness, but they were further away and faint. I felt a power like a vacuum pulling me into it further. As I moved toward the source, my speed increased proportionately. (G. Wells, personal communication, 1994)

He heard his own voice yelling to God for help, and suddenly the scene was gone. This was followed by a powerful, enlivening sense of the presence of the Holy Spirit.

In another case, Norman Van Rooy as a child of 4 or 5 one evening heard his name called as he lay in bed before going to sleep.

There was a kind of humming . . . or throbbing sound like electricity in a transformer. . . . It had a malevolent intelligent magnetism that was almost hypnotic. ... The sound was coming from the wall. As I watched in horror the wall opened up in several places near the floor and out of each opening came a creature. These were shaped like the bottom sides of goat's hooves. I felt helpless as they beckoned me to come with [them]. Between the cloven hooves from where their voices came a nexus of overwhelming magnetic malevolent intelligence pulsated with a fiery glow. They seemed to know me and were trying to pull me down with them. ... This frightened me terribly and I called out for help to my mother who was in the next room. When she entered the room the entire scene disappeared. ... When she left this event was repeated. I felt weaker and sensed I could not resist and would be sucked into their subterranean world. Again I cried out and again my mother's presence dispersed [them]. . . . I fell asleep. . . . The next night this was repeated. After that I never re-experienced anything remotely similar to it. (N. Van Rooy, personal communication, 1994)

The fact that Van Rooy's experience happened in bed in the evening may prompt some readers to interpret it as a nightmare. Unless one is given to reductionism, there is no reason to doubt that it was a waking experience just as he recounted it. There are, however, analogies between the experience and nightmares peopled by menacing figures, especially those that are not a processing of past traumaswhich fact suggests that rather than his vision being "merely" a nightmare, the malevolent figures in certain nightmares may in fact be a form of the same kind of entity, possessing a kind of reality of their own.

Both these not-close-to-death experiences centered around evil entities and an evil force, and there is a hint of hellfire in the second one. But there are also cases, both NDEs and not-close-to-death experiences, that center around hellfire but have no entities, or whose entities lack power or malevolence. Rawlings cited two of them in Beyond Death's Door (1978). One was the case of Thomas Welch, who 
fell from a trestle high over a dam. He found himself near the shore of an awe-inspiring lake of blue fire. Deceased persons he had known were there, looking bewildered and incredulous. He was rescued by the figure of Jesus, who turned and looked at him. Then he was back in his body.

One can also find accounts of hellfire-centered not-close-to-death experiences in the lives of saints and mystics. Teresa of Avila-who may have been an NDEr, having once been in a deathlike comawhile praying suddenly found herself in hell: a long narrow passage, whose ground was covered with malodorous mud full of reptiles, which led to a small cavity in a wall in which she was then confined. She suffered physical-seeming agonies of being both burned and dismembered, in terrible despair because of her conviction that this would be forever. She did not tell how she escaped (Teresa of Avila, 1957). I mention Teresa's case, which was quoted at some length in Christopher Bache's "A Perinatal Interpretation of Frightening NearDeath Experiences" (1994), because she also had a not-close-to-death experience in which a fiery spear pierced her heart; she interpreted the fire as divine love-a common image among Christian mysticsand found it both blissful and agonizing at once. I will develop some of the implications of this ambivalence below.

P.M.H. Atwater, in Beyond the Light (1994), noted that spinning vortices and other whirling patterns turn up in some distressing NDEs, as well as in her own radiant third NDE. Marcel Louis Forhan ("Yram"), who in his book Le Medicin de l'Ame (translated as Practical Astral Projection) described having out-of body experiences virtually at will, mentioned vortex-like energies that would sweep his projected self away into sometimes unpleasant situations (Yram, 1974). With knowledge of more cases, we may find the vortex-centered distressing NDE to be a third subcategory.

\section{The Empathetic Life Review}

In addition to Greyson and Bush's three types, a possible fourth type of (partially) distressing NDE is the painful empathetic life review. The empathetic life review was described in Moody's Reflections on Life After Life (1977) in a chapter entitled "Judgment." He cited cases of persons who experienced not only every detail of their lives but also the impact of their lives on others. He suggested that people who have done great harm, such as perpetrators of the Nazi horrors, 
seeing all the suffering they have caused, and by implication, feeling it, would undergo the worst sort of hell imaginable. Atwater, hardly a sinner in the Nazi league, also used the word "hell" to describe her empathetic life review, which included the effect of her life not only on other people but on animals, plants and the so-called inanimate world: "It was a reliving of the total gestalt of me as Phyllis, complete with all the consequences of ever having lived at all" (Atwater, 1988, p. 36).

Dannion Brinkley, in Saved by the Light, wrote that in his empathetic life review he not only received all the violent kicks and punches he had delivered in the thousands of fights of his youth, but felt the death-throes of the people he killed in Laos and Cambodia, the suffering of their families afterwards, and also the deaths of civilians killed in his presence by other military personnel (Brinkley and Perry, 1994). He also mentioned feeling the suffering of a dog he had once beaten for a minor misdeed, as well as the relief of a goat whom he had rescued from another's abuse.

To experience the effects of one's life may seem like an exact sort of recompense-perfect justice-for the Adolf Hitlers of this world. But "all the consequences of ever having lived at all" includes unintended consequences as well as future generations. Suppose we move back a generation: did Klara Hitler, a doting mother who lacked the courage to protect the child Adolf from the savage abuse of his father (Miller, 1990), deserve to experience the entire Holocaust and all the rest of the horrors of the war?

No returned NDEr has described in any detail a "ripple effect" of this magnitude, but the fact that most are limited does not mean that the ripple effect does have limits. It may be a preliminary form of the vision of knowledge that Moody's subjects and other NDErs described when they said things like "There was a period in which I knew everything." But knowing everything may be a decidedly mixed blessing. If the sins of the children, generation after generation, are visited upon the fathers and mothers, we have indeed a situation that often could rightly be called hell, though it is not exactly an otherworldly state but a retrospective hell on earth.

\section{Otto's Mysterium Tremendum}

The history of religions can be helpful in providing contexts for the phenomenon of distressing NDEs. Of particular value is the analysis of the German thinker Rudolf Otto presented in his classic 
work Das Heilige, translated into English as The Idea of the Holy (1958). Otto's analysis is relevant to Greyson and Bush's three main types, but not to the empathetic life review.

He asserted that the essence of deity is not expressible in intellectually meaningful categories, but that so-called divine attributes are rationalizations applied to the human experience of the Holy, which is an encounter with a nonrational Something that he described as the Mysterium tremendum et fascinans, the Dreadful and Fascinating Mystery. He coined the term "numinous," from the Latin numen = divinity, to express this sense of a felt presence that is so alien to our everyday world, so uncanny, that the mind that encounters it is struck with blank astonishment, with awe. The hair-raising feeling aroused by ghost stories is, wrote Otto, a degraded form of the response to the Mystery. It is because the Mystery is so totally Other that words fail to describe it.

The dreadful aspect of the numinous perception is not merely dread in the sense of fear of a this-worldly threat; it involves a shudder of supernormal horror, the feeling of the blood running cold. Otto saw an early expression of this kind of experience in the concept of the Wrath of God in the Hebrew Scriptures. In many passages it seemed clear that this Wrath had no concern at all with moral qualities; the ways in which it was aroused were baffling. It is "like a hidden force of nature,' like stored-up electricity, discharging itself upon anyone who comes too near" (Otto, 1958, p. 19). But the term "wrath" is an image, wrote Otto, an attempt to understand the experience by applying the analogy of human anger.

Carrying the analysis further, Otto remarked that there is something enormous and overpowering about the Dreadful Mystery. By contrast, the human self is puny virtually to the point of nonexistence; one cannot even consider pitting oneself against it. Thirdly, there is an element of intense energy about the Dreadful Mystery. It is alive; it is at the furthest possible remove from mere philosophical abstractions. In some forms of mysticism it appeared as the " 'consuming fire' of love whose burning strength the mystic can hardly bear" (Otto, 1958, p. 24).

The same mysterious Something that arouses astonishment, awe, and dread also arouses a powerful fascination in the one who perceives it. The experiencer of this fascination "feels a strange ravishment, rising often enough to the pitch of dizzy intoxication" (Otto, 1958 , p. 31). As with wrath, the conceptions of this Fascinating Mystery as comfort or security or the joy of love are inadequate images 
for the unutterable bliss it conveys. Many means are employed to seek out the Mystery, including magical operations and severe asceticism. One may begin by seeking it for what one has to gain by it, but will sooner or later seek it for its own sake (Otto, 1958).

Otto did not mention the near-death experience; his analysis was based on his study of traditional religious phenomena from many times and places. Yet his Dreadful and Fascinating Mystery described remarkably well the feeling tone of heavenly NDEs and hellish-type distressing NDEs. His analysis is helpful for our purposes for at least two reasons. One is that it validates the existence of hellish NDEs as part of a wider spectrum of baffling religious phenomena. The other is that he asserted from the outset that these phenomena are nonrational; he attempted to get below any interpretation and valuation to explore the nonrational core of the experiences.

In fact he did not quite succeed in getting beyond interpretation, as can be seen, for example, in his assumption that the Dreadful experiences and the Fascinating experiences are all encounters with the same reality. There are mystical experiences that clearly manifest both qualities, as in the case of Teresa's fiery spear, but in other cases, in which only the one or the other quality is present, it is not evident that both are of the same kind. Further, it must be admitted that in some NDEs the interpretation is not merely imposed in retrospect but is unmistakeably part of the imagery of the experience. An example is the painful case of NDEr A.B., published in the newsletter of the Seattle IANDS group. Overwhelmed by darkness, a loud bell, and the screams of seeming thousands, badly frightened, she was warned that the sin of adultery in her life had led to this pass (A.B., 1991).

However, it is still profitable to follow Otto and regard interpretations of NDEs as at least to some extent secondary to the basic encounter, as this enables us to put various interpretations side by side and evaluate them. Interpretations are meaning structures, part of the overarching meaning structure that is a culture's worldview. The core principles of a meaning structure are selection and subordination; by this means patterns are shaped and perceived. Without necessarily being aware of it, when we look at a field of data, we see the polarity of figure and ground; for example, when we read we look at the black shapes on the page, ignoring the white configurations inside and around them.

Another important polarity is that of good and bad, which is obviously important when considering heavenly and hellish experiences. Complications arise, however, which will be considered later. 
A third polarity of meaning structures is the real versus the illusory. For example, those who hold to the reigning scientistic worldview in our culture explain away heavenly and hellish visions alike by calling them hallucinations, that is, claiming they are illusory. Many readers of this Journal would instead take an opposite tack, asserting that the heavenly NDEs, at least, are real. But there are also complications here which will be gone into later.

Immanuel Kant's critical philosophy took the lead in making Westerners aware that worldviews are created and sustained by human beings. This happens in thousands of complex and subtle ways; limited human beings cannot see reality bare without them. Some thinkers have assumed that this means that reality, as it is in itself, is chaotic, perhaps meaningless; certain psychedelic and mystical experiences, and the everlasting void type of distressing NDE, tend to foster this idea. But we need not commit ourselves to it; for all we know, reality itself may in fact approximate to some particular worldview, or a roughly accurate worldview may be gleaned by careful cross-cultural comparisons.

In any case, we cannot think without a worldview, and those who explore near-death studies have to fit distressing experiences into it somewhere if we are to be honest enough to admit their existence. For this reason I do not join Otto in calling the Dreadful and Fascinating Mystery simply nonrational, but will try to bracket the issue while I outline some basic interpretations of how the two kinds of experience relate to one another and to everyday life.

\section{Types of Rational Paradigms for Explaining NDEs}

Interpretations are largely of three kinds, which I will call the supernaturalistic, the reductionistic and the one-world types, my typology being developed from philosopher David Griffin's typology of philosophical animism and dualism (Griffin, 1993).

\section{Supernaturalistic Paradigms}

Supernaturalistic thinking has shaped the major Western religions and influenced the rise of modern science, so it is very familiar to us. Essentially, it gives us a crucial division: on the one hand a sovereign God and the world of pure spirits; on the other hand the public 
physical world. God is all-powerful, and creates and rules everything in both worlds. Physical things are "dead" and and can only react according to the physical laws God has set; they have no choice of any sort. But we human beings may choose to obey or disobey God's moral laws. To some extent we may get our rewards and punishments in this life, but that cannot be counted on; what can be counted on is heaven for the obedient or hell for the unrepentant after death. In this interpretation, then, to oversimplify, hellish NDEs reflect experience of a state that is God's work, the expression of his rage at human disobedience. If demons are involved, they are carrying out God's will.

A variant on this hell-as-punishment interpretation has already been noted in the case of Drythelm: purgatory, as a third state between heaven and hell. Here suffering still results from sin against God, but rather than being an expression of God's retaliatory anger, it is motivated by God's good will, with the purpose of purging sinners to fit them for heaven.

A second variant we saw exemplified in the fundamentalist interpretation cited above. Christian fundamentalism is a 20th-century development, arising out of 19th-century revivalism and the conflict with modern science, but it has roots in the ancient and medieval theologies of Paul, Augustine, and Anselm. It interprets Jesus' crucifixion as meaning that God's compassion sought to find a way to circumvent His wrath by providing the death of Jesus as a sacrifice to expiate for sin. All people are sinners deserving hell; living an apparently good life is not enough to get one to heaven. One must confess one's sins and spiritual helplessness, and turn to Jesus as Saviour, accepting His death on the cross as a substitute punishment for sins. This act makes it possible to go to heaven after death.

The corollary of this view is that all those who do not go though this Christian conversion process will go to hell, however good and admirable their lives may be; thus Rawlings' abovementioned view that the unconditional divine love of blissful NDEs is actually a deceit of the devil. It should be noted that a great many Christians who accept this interpretation do not accept the corollary, but leave the matter a mystery.

\section{Reductionistic Paradigms}

Interestingly enough, a supernaturalistic and authoritarian worldview akin to this actually led to the development of modern science 
in the 17th century, and eventually to the reductionistic interpretation, as Griffin (1993) has pointed out. Rene Descartes is well-known (or notorious) for having articulated the philosophy of a basic bifurcation of mind and matter upon which the edifice of modern science was largely based. It was only when physical reality was thus seen as essentially inert and "dead," operating under principles and laws put into it at the beginning by God, that it could begin to be studied objectively and for its own sake.

But when matter and spirit were split off like this it became increasingly difficult to see how they were related at all. The reality and nature of the physical world became more and more impressively shown, but God and the human soul came to seem less and less real. They were also suspect because they were associated with repressive religious authority. The result was the creation of a reductionistic cultural climate in which it seems to most educated persons quite appropriate for NDE stories, including the hellish type, to be dismissed as hallucinations by medical and academic authorities who have scarcely looked into them.

\section{One-World Paradigms}

Most other interpretations of hellish experiences are of the oneworld variety. According to this kind of worldview, which is the oldest, the spiritual and the physical are two dimensions of the same reality. For example, among many tribal peoples and with certain Renaissance thinkers, Gods, angels, demons, nature-spirits, the deceased, humans, animals, plants, and stones may differ greatly in degrees of power and consciousness, but as part of the same world are all essentially of the same kind. Every action has spiritual effects. Everything is alive to some extent, and energy may be seen as flowing through all things. For this reason religious ceremonies, magical operations, meditative states, blessings, and curses are powerfully efficacious, must be handled with care and under the proper circumstances.

For adherents of the reductionistic worldview, this kind of magical world is so much superstition, though underlying their scorn may be unacknowledged anxiety. It is also anathema to many supernaturalists, who tend to feel anxious outside the secure circle of a world governed by infallible religious authority, such as Scripture or Pope, giving forth the will of a sovereign Deity. The great flowering of one- 
world outlook in the West came in the Renaissance; it struggled with, and was defeated by, authoritarian religion and modern science (Griffin, 1993). But it is blossoming again in our own times with New Age, ecological and mystical thought, and certain worldviews based on contemporary physics.

The Spiritualistic Paradigm. Perhaps the oldest interpretation of the one-world type is spiritualism, as many primordial peoples are spiritualists. Spiritualism received a powerful boost beginning with the well-known events in the house of the Fox sisters in New England in 1848, and is the basic outlook of many millions of people today, especially in Africa and Latin America. Though spiritualism is held in contempt in many academic circles, like any religion it ought to be regarded with an open mind.

One of the central tenets in this view is that human souls, as well as animal souls, survive death as a unit of consciousness. Since there are many human beings in the flesh who are evil, who will not be transformed simply by dying, it stands to reason that there are also many surviving evil spirits. There may also be evil entities who have never been in the flesh. In the various spiritualistic subworldviews, evil spiritual beings may become earthbound, influencing the living for ill, or may gravitate to a spiritual "lower astral" plane among others of their ilk.

In any case, the menacing beings who come to draw NDErs and not-close-to-death experiencers, the parasitic and angry beings witnessed by Ritchie, the sadistic ones who victimized Storm, are in this interpretation very much what they appear to be: real entities with an inner life of their own, if life it can be called. They relate by spiritual laws to one another and to the living. One basic law is that like is attracted to like: fear and hostility will attract angry spirits, love will attract loving ones. Another law, especially among modern Western spiritualists, is the principle of spiritual development. No being is purely evil; all have the potential to evolve from lower planes of darkness to higher planes of light and love. This usually requires the help of highly evolved compassionate beings, such as those in the distressing experiences cited above.

The Consciousness-as-Creator Paradigm. Another type of one-world interpretation, sometimes seen in conjunction with the spiritualistic, is the consciousness-as-creator interpretation. Tibetan Buddhism is a good example of this outlook, as may be seen in the well-known Tibetan Book of the Dead (Evans-Wentz, 1967; see also Ring, 1994). According to Buddhism there really is no such thing as a soul; the 
self as a kind of spiritual kernel in the physical shell is an illusion. When we succeed in fully getting rid of the illusory ego, our consciousness realizes infinity and we are free from all the ills of individualized existence. According to this view, some of the figures seen in distressing NDEs may be ephemeral phantasms, but others such as the terrifying Buddhas in the Tibetan Book of the Dead (EvansWentz, 1957) may have a much more durable-seeming existence, having been created and sustained by generations of Tibetan Buddhists in meditation and in the afterdeath state.

The important thing is to realize that these entities, according to this view, maintain their power by our taking them at face value. When we refuse to do this, and see them as creations of consciousness, they lose their power over us. The dying person is often reminded in the Tibetan Book of the Dead (Evans-Wentz, 1957) that the terrifying Buddha of a particular sort is the same as the glorious one of that sort. When one overcomes one's fear and revulsion and accepts the demonic figure as a destroyer of the illusory ego, one is freed from the compulsion to reincarnate, and can definitively unite with the Clear Light of the Void. This interpretation is clearly applicable to inverted NDEs, especially those which become joyous after the experiencer changes his or her attitude.

From the consciousness-as-creator point of view, not only the demonic "welcoming committee" and the flaming pit, but even the traditional God who damns sinners to it have been brought into such existence as they have by the vengefulness and fears of generations of religious persons. Pain-giving though such entities may be, they are no more real than the ego that suffers them. When accepted as illusory, they can serve the same purpose as the terrifying Buddhas of the Tibetan Book of the Dead (Evans-Wentz, 1957), to destroy the ego and release one into the light.

The Mythical Paradigm. Another kind of one-world interpretation, linked to the above, may be called the "mythical" or "mythopoeic." The scholarship of Joseph Campbell in The Hero With a Thousand Faces (1949) and Northrop Frye in The Secular Scripture (1976) have given us a good deal of insight into this theme, which they have traced in myths, folktales, and literary works. J.R.R. Tolkien's The Lord of the Rings (1974) and George Lucas' Star Wars film trilogy gave good examples of the scenario itself.

Essentially, the scenario presents us with a hero or heroine who begins in an ordinary, limited setting, unaware that she or he is of royal blood or possesses supernormal gifts. Something is wrong in 
this world, according to Campbell; it is diseased or in some way doomed. To meet this need an event or messenger appears that calls out the hero or heroine. To those left behind, this departure amounts to a death. But far from really dying, he or she moves into a larger world full of extraordinary beauties and indescribable horrors. This is the "downward" action of the story, according to Frye.

At the nadir, the hero or heroine suffers excruciating pain, perhaps a tortured prisoner in a cave or dungeon, perhaps battling a horrifying monster or other enemy. This is the second death, the equivalent of hell. Then comes the "upward" movement: the hero or heroine is rescued or escapes the dungeon and defeats the enemy, who turns out to have been guarding a magnificent treasure. The heroic one eventually returns home, making the treasure available to her or his world and healing that world. There may be an enthronement or a royal marriage celebrating the new dawn of light and love, the new springtime (Campbell, 1949; Frye, 1976).

There are clear analogies between this storied hero-adventure and distressing NDEs: the downward movement, loss of identity, darkness, entrapment, pain and horror, demonic enemies, rescue, and return upward. The gaining of a wonderful treasure, briefly known in the joy of the light, is not often experienced as part of the NDE itself, though it was indeed part of the story in the cases of Storm and Drythelm. It may come in a separate NDE (Rawlings, 1978). More often the NDEr returns terribly shaken, and the potential for renewal is developed later in his or her resumed life.

The Western Mystical Paradigm. The final one-world kind of interpretation that I offer I will call the Western mystical path. I use this name because it is derived from studies of Christian mysticism, but in fact it also applies to some Eastern mysticism. It is based partly on not-close-to-death experiences.

Western academic scholarship on mysticism began about 100 years ago. The first and second generations of scholars were concerned to trace common themes among mystics of different traditions, in an attempt to gain insight into the nature of the Ultimate, the Divine, which all mystics were held to have experienced. Many contemporary scholars of mysticism are moving in a different direction, emphasizing the context-dependent nature of all mystical experiences and mystical accounts, and concluding that it is impossible to experience the Ultimate unconditionally, in that all spiritual experiences are influenced by cultural expectations (Katz, 1978, 1983). That all mystical accounts are culturally conditioned is a truth that needs to be 
emphasized, but I am unconvinced that an agnostic view necessarily follows. In affirmation of the essentials of the position of the firstgeneration generalists, I will draw on the work of English scholar Evelyn Underhill (1875-1941).

In her mammoth study Mysticism, Underhill (1911) presented the mystic's path as a journey of five stages. This was her expansion of an ancient three-stage version of the path. It was an approximation summarized from the accounts of many Christian and a few Islamic mystics; she acknowledged that many mystics did not in fact fit it exactly. Some may have skipped a stage or reversed two stages, or the like.

Underhill's first stage was Awakening. The future mystic suddenly or gradually becomes aware of an unutterable splendor in the world, a loving divine Presence, occasionally of a supernormal terror. The awakening may take the form of perception of the light, of a psychedelic glory in nature, of a voice such as St. Francis heard from the crucifix of a ruined church; or it may be a seemingly ordinary event that resonates deep within. I compare this first stage to the situation of a person who has moved into a house in the desert. She or he goes out one morning after a rain to find that the desert has exploded into glorious bloom.

The first stage is wonderful but it doesn't last. The light has given the mystic new values and joys, but has also shown him or her up as having many dark corners within, unhealthy habits, false values, egotism, and unkindness, such as are so common.

The second stage, then, was Purgation. The mystic is no longer going the way of the world, and will have to gather the courage to look like a fool at times, often to do things that alienate loved ones. It will often mean setting up a regime of prayer or meditation and following it even when one feels "dry" and unrewarded. The ancient and medieval Christian mystics Underhill studied also tended to have a strong bias against the body, and their Purgation activities include abusing themselves in ways most of us would consider unhealthy. But even without that, Purgation is a time of dislocation, gruelling work, and considerable pain. In the image of my desertdweller, Purgation means building a garden around one's house. It involves laboring under the hot sun, digging wells and irrigation channels, planting, weeding, and fertilizing.

The third stage was Illumination. The work of Purgation begins to bear flowers and fruits; there is a deep sense of divine presence much of the time; prayer or meditation bring deep strength and joy. 
Paranormal gifts may appear. Love for the world flows through one. The desert-dweller has many happy hours sitting in the shade of her or his garden, enjoying the blossoms and the fruits. The second and third stages may take the form of more or less rapid alternations back and forth, a situation some mystics have called the Game of Love, and in fact such a mixture of work and gratification prevails with gardening much of the time, too.

The fourth stage was the Dark Night of the Soul. The pain of this stage is worse than anything dreamed of in Purgation. The divine presence is gone, evidently forever. The mystic feels categorically rejected by God, alienated from all friends and family members, with no identity, with a burning thirst for the love once known. Evil thoughts may come and obsess one; demonic figures may taunt or torture.

The Dark Night, which seems so final to the mystic, is not in fact the last word. It transmutes, sooner or later, into the Unitive State, a sustainedly blissful condition that still oddly bears some of the characteristics of the Dark Night. There is no need for particular times or places of religious observances. There are no particular friends or loved ones, perhaps not even a sense of greater kinship with people than with animals or stones; recall St. Francis with his Sisters the Birds and Brother Sun. The mystic never regains his or her lost identity as a religious person. But none of this is needed, for the darkness and the light turn out somehow to be the same thing. There is no need for the house and garden to be rebuilt, for everywhere is home. To paraphrase William Blake, "Every grain of sand a gem/Resplendant with the Light Divine" (Williams, 1952, p. 232). Or, as in the renowned line from the Koran, "Whithersoever you turn, there is the face of God" (Arberry, 1955, p. 42).

Meaning, which involves selection and subordination, is almost wholly discarded, for all is an ocean of glory. I might add that Underhill saw the mystic in the Unitive State as speaking absolutely reliable truth, as offering unlimited divine love. But here the point of Steven Katz $(1978,1983)$ and his colleagues is salient: one may affirm that such a mystic does possess great power and wisdom without necessarily having transcended humanness, or indeed the concepts of her or his culture. In short, sometimes he or she is idiosyncratic, or just wrong!

I repeat that most mystics do not take the five stages in neat order. And the possibility that this path is in essentials equivalent to the path of profoundly transformed NDErs, which I believe it is, may 
help to explain why persons who have undergone distressing NDEs may be blocked for a long time from entry into the Unitive State, especially if they lack spiritual guidance, and that some persons who have had blissful NDEs may appear to have moved from Awakening through some form of Purgation and Illumination into the Unitive State or its equivalent without a Dark Night of the Soul.

Mystical and near-death experiences so often involve a sense of time having disappeared, as to suggest that the painful and the blissful experiences-indeed, all events-somehow happen at the same time. For example, we noted above that Holladay interpreted her painful mystical experience with the mirror in 1987 as a delayed unfolding of certain dimensions of her presumed NDE of 13 years earlier. If this is the case, they then merely appear to our limited embodied consciousness in an order more or less meaningful to us. It is possible that some "stages" may not become apparent until after one has left the flesh.

\section{The Dark Night of the Soul and the Distressing NDE}

Since this paper deals particularly with painful NDEs, I wish to concentrate here on the claimed analogy or identity between stage four, the Dark Night, and distressing NDEs. Many examples could be chosen. I will sketch the experiences and reflections of three mystics, George Fox, Juan de la Cruz (John of the Cross), and Jacob Boehme, and compare them respectively to the demon-haunted NDE, the everlasting-void NDE, and the hellfire-NDE.

\section{George Fox and the Demon-Haunted NDE}

George Fox (1624-1691), co-founder of the Society of Friends (Quakers), may actually have been an NDEr, as on at least two occasions he underwent trances so deep that those about him were uncertain whether he was living or dead. He had visions of the divine light not only in trance, appearing as an ocean, but in his waking state, as stars or sparks in human hearts and in the earth. These perceptions of the light were so important to his ministry that the Inner Light is still the central image for the Divine in the Society of Friends. 
During one of his prolonged altered states of consciousness, which took place during the national turmoil of the breakdown of the English Commonwealth in 1658, "a company of evil spirits" came and harrassed him (Fox, 1952, p. 356). Little detail is given about this experience. In a more severe ordeal of this sort in 1670 , during a period of violent persecution of Friends, Fox suffered blindness and deafness in an altered state of consciousness over a period of several months. "And great sufferings I was under at this time beyond words to declare, for I was come into the deep, and the men-eaters were about me and I warred with their spirits" (Fox, 1952, p. 571).

This rather obscure passage may be clarified by comparing it with another one two pages later in which the term "men-eater" is applied to some of the clergy of the Established Church. Fox's denunciation of greed and exploitation in high places aroused the wrath of powerful church leaders who were profiting from the status quo; some of them were behind the current persecution. Fox referred to them as "men-eaters" who "preached peace to people if they put [food] into their mouths and fed them, but if not they gnawed their flesh off to the bone and chopped them for the cauldron" (Fox, 1952, p. 573).

The "spirits" of the "men-eaters" who tormented Fox in his trance may then refer either to these living people who were torturing him telepathically, or the devils that were motivating them to do so. This interpretation is in keeping with many incidents in Fox's life that we would class as paranormal, including clairvoyance, telepathy, psychokinesis, healing, and the like. In any case, whatever the ontological nature of these perceived evil spirits, Fox's reaction to them was one of fierce warfare, in contrast to his nonviolent stance in regard to his enemies in the flesh.

In common with many of his time and place, Fox had interpreted the upheavals of the 1640 s and '50s as signs that the end of the world was upon Christendom. But by 1658 and especially by 1670 it had become apparent to him that the Judgment and the final victory of Christ over the dark forces, which he had thought to be imminent, were not taking place. It is possible that Fox's ordeals also partook of the nature of disillusionment corresponding to the breakdown of belief we have seen to be characteristic of the Dark Night, although he did not say so.

During this same prolonged period of altered consciousness Fox also had blissful visions of the New Jerusalem, which he understood to be both a present reality in the depths of the soul and an image of the transformed world soon to come. The vision of this City of 
Light was a strong reaffirmation of the heart of his faith that, despite persecution and disappointment, the light and spirit present in all persons would come to consciousness in all and be vindicated. It should be noted also that he understood this vindication to be a state of consciousness of universal dimensions, which he called the Day of Christ: "In his day all things are seen, visible and invisible" (Fox, 1952 , p. 29). It is the dispelling of ignorance and awakening from sleepy stupor to awareness of all things. There is an evident analogy to what Moody (1977) called the "vision of knowledge."

Fox affirmed the existence of hell as the final state of the unrepentant. He did not see them as totally cut off from God, for the Inward Light cannot be put out. Rather their sufferings in hell are the inevitable result of their own continued war against the light and spirit within, which evokes the spirit's condemnation. One might say that they are punished not so much by God as by the nature of reality. It should be noted that, far from being the victim of a schizophrenic disorder such as his tales of demons might suggest to a reductionistic thinker, Fox was a brilliant exegete of the Bible, a powerful preacher, a competent organizer, and was totally fearless in the face of mob and judicial violence.

\section{Juan de la Cruz and the Everlasting Void NDE}

The Spaniard Juan de la Cruz (1546-1591) was a mystic of a substantially different style, to whose poetry and writings of spiritual guidance we owe the term "the Dark Night of the Soul." Less interested in spiritual knowledge than Fox, or in action toward social justice, he was oriented toward the soul's personal union of love with God. This was to be achieved by rigorous processes of self-stripping until one has emptied oneself utterly. The various stages of this process he referred to as so many forms of the Dark Night: the Dark Night of Sense and Desire, the Active Night of the Spirit, the Active Night of Memory and Will, the Passive Night of the Senses, and the Passive Night of the Spirit. These stages became progressively more terrible until they finally gave way to the Spiritual Marriage, which was his chief image for the Unitive State (John of the Cross, 1946, pp. xxv-xxix).

The Dark Night of Sense and Desire had as its aim the detachment of the mystic from all gratifications of sense, from all created things. Juan referred particularly to cravings for food, which he probably 
meant literally as well as symbolically: "the bread of angels is not given to, neither is it meant for, that palate which is pleased with the bread of man" (John of the Cross, 1946, p. 7). As further examples of things to be given up he lists "much talking, certain attachments . . . such as to individuals, to a book or a cell, to a particular food, to . . . science, news, and such things" (John of the Cross, 1946, p. 10). The mystic was also to give up the gratification of being wellregarded, and must disparage himself. This sacrifice of physical gratifications can be compared to the acceptance of the cutoff from the physical world that takes place in peaceful NDEs, with the significant difference that for Juan and his mystical followers, physical life was not usually interrupted.

The Dark Night of Sense and Desire Juan compared to dusk, when there is still some light to see by. The Active Night of the Spirit, by contrast, is total darkness. It has to do not with affairs of the body and the social self, but with God and spiritual things. One must give up not only reason and understanding, but the spiritual meditations and devotional practices that had given spiritual delight earlier. $\mathrm{He}$ compared this state to Jesus' cry of dereliction on the cross: 'My God, my God, why hast thou forsaken Me?" (Matthew 27:46). All our conceptions of God must be given up. This stricture applies not only to language and visualizations but to visions of saints and angels, perceptions of light, touch, fragrance, and the like.

Juan acknowledged that such experiences may be from God, but they may also be from the devil; even if they were from God, to reject them does not offer wrong to God, because "the fruit that $\mathrm{He}$ desires to bring forth in the soul" will take place just as well when one walks only by faith (John of the Cross, 1946, pp. 22-24). There is little doubt but that Juan would be unimpressed by radiant NDEs, whether visions of the light, of Christ, of angels, of paradise, or whatever. He granted that such things had their uses for beginners, but the maturing soul must leave behind all images and learn to wait quietly upon God in the darkness.

The Active Night of Memory and Will was a condition in which one willed to forget all knowledge of all things gained through the senses. "The memory must be stripped and emptied of all this knowledge and of these forms; it must labour to destroy all sense of them ... as completely as if they had never entered into it . . . if it is to be united with God" (John of the Cross, 1946, p. 53).

The Passive Night of the Senses was a state of emptiness that came over the mystic, who "find[s] no comfort in the things of God, 
and none also in created things." Juan, as did Johannes Eckhart and Jan van Ruysbroeck and Teresa before him, referred to this condition as dryness, and a favorite image for it is the desert, as aforementioned. "The cause of this dryness is that God is transferring to the spirit the goods and energies of the senses, which, being not unable to assimilate them, become . . parched up, and empty" (John of the Cross, 1946, p. 81).

But the spiritual contemplation that has begun is still so dim that the person is not aware of it. This Passive Night of the Senses is very distressing to the soul, who fears being lost spiritually, and feels forsaken by God because prayer and meditation on holy things, which before were so rewarding, now mean nothing. Some mystics also suffer painful trials: "the angel of Satan" is sent to them, "to buffet them with horrible and violent temptations" (John of the Cross, 1946, p. 89). Despite appearances, these trials have a purgative purpose, according to Juan.

The Passive Night of the Spirit is the hardest of all, with "terrible torments" that prepare the soul for the supreme union. This darkness is in fact "a certain inflowing of God into the soul," an intense purity and brightness, but because the soul is still imperfect and impure, the light transcends the soul's capacity and is perceived as darkness. The soul's wretchedness is fully revealed, leading to utter misery. The

greatest affliction of the sorrowful soul in this state is the thought that God has abandoned it, of which it has no doubt; that He has cast it away into darkness as an abominable thing. It has also the same sense of abandonment with respect to all creatures. (John of the Cross, 1946, pp. 94-96)

The analogy between this sense of abandonment and the terrible aloneness of the void cases is unmistakeable.

Another aspect of the Passive Night of the Spirit Juan expressed with the image of the "dark fire of love": "The soul begins to burn in the darkness." This is God's love and the soul's love at the same time. It is a wound, yet at the same time is sometimes "an inward strength," whose working the soul cannot understand (John of the Cross, 1946, pp. 102-103). The intensity of desire for God is such that the mystic may disregard all considerations, and do strange and extravagant acts. Juan expressed this recklessness in his well-known poem "Noche Oscura [On a Dark Night]," in which the narrator, 
"starving for love and deep in flame," stole out of her house in the darkness to find and lie with her lover (John of the Cross, 1972, pp. 38-41). In violently puritanical Spain, by such an act she risked her life and gave over all identity and human connection except that with her lover.

Juan described no single dramatic movement from the deepest darkness of the Night to the bliss of spiritual union. Just as the approach of the Night was gradual, through the twilight of the Passive Night of the Senses, the approach of ultimate fulfilment is through the dimness of predawn. Suffering begins to give way to intermittent experiences of joy in the divine presence, and an awareness of the presence of God in all things. Juan called this stage the spiritual betrothal. It is followed by the spiritual marriage of uninterrupted union:

This is, beyond all comparison, a far higher state than that of betrothal, because it is a complete transformation into the Beloved; whereby they surrender each to the other the entire possession of themselves in the perfect union of love, wherein the soul becomes divine, and, by participation, God, so far as it is possible in this life. (John of the Cross, 1946, p. 167)

When we compare these descriptions to the sketch of the everlasting void type of NDE given above, several analogies become evident. Most obvious is the darkness, a figure of speech for the poet Juan, a perceived reality for the NDEr. Darkness as symbol has several meanings: inability to see one's way by the light of reason; anxiety or terror; inability to relate to the everyday world, from which one has become separated. The desert/outer space image conveys sterility, emptiness, terrible thirst, and longing for one's source of love. This is the Nothing. There may be difficulty in remembering one's past, and mockery by mechanistic entities, analogous to Juan's "angel of Satan," as in one of the void cases cited by Greyson and Bush (1992).

Contemporary NDEs go one step beyond Juan in conveying a sense that ordinary life with all values is meaningless and a delusion. In both cases the sufferer is convinced that her or his dereliction is permanent. In both cases, however, this turns out to be not the case. Juan showed that the experience was in fact a stage, an initiatory ordeal. NDErs are returned to the everyday world, and some of them come to see their ordeal in ways analogous to Juan's conception. 


\section{Jacob Boehme and the Hellfire NDE}

Boehme (1575-1624), a German mystic of Lutheran persuasion, used imagery of darkness as did Juan, but it was imagery of fire that he developed in great depth. Fire had no single meaning consistently throughout his writings, which were produced over a period of some twenty years, but a certain pattern can be traced throughout.

For Boehme fire was not a means by which God punished the wicked in hell, although Boehme did affirm the reality of hell as the abode of the unrepentant. Fire represented rather the basic energy of all life and all creation. "It is life's first principle, the soul's first root" (Stoudt, 1968, p. 115). For Boehme, all began with a dark Nothing that was incipiently Something but was not conscious of that Something. The Nothing was totally formless; Boehme also called it the Unground and the Abyss. This Nothing desires and seeks, its impassioned search being the original Fire. "The Nothing reaches to Something and discovers itself in it. It is an eye that sees itself in its own reflection looking back" (Boehme, 1978, p. 18). That which it sees, the Something or the Ground of the Abyss, it desires with the burning flame of love.

Out of this basic dialectical movement the Trinity was born, said Boehme. All things that potentially exist were known in the divine self-contemplation. This eternal creativity was expressed in the figure of the Virgin Sophia, divine wisdom, the celestial body of God, who was like a mirror in which the forms of all things were to be seen. Sophia was called a virgin because she represented not the blazing energy of fire but the blissful peace and total consciousness of light. The fire longs for the light, and the light needs the energy of the fire. In the true divine nature, the fire and the light are united in perfect balance, which Boehme called the temperamentum, the divine love-play, the coincidence of opposites (Boehme, 1978, p. 19).

The myriad of things that God conceived in wisdom came into separate existence in a flash by God's creative fiat. Adam, the androgynous human being, was the highest point of creation, made to the image of God in Sophia; the angels were also created. Here we have the Three Principles or Three Worlds: the Eternal Fire, the Eternal Light, and the world of physical creatures that they reflect and generate. Every creature contains both the fire and the light within itself.

Together with the coming-into-existence of the creatures, the catastrophe of the Fall took place. The angel Lucifer disrupted the mys- 
terious balance of the coincidence of opposites by his attempt to hold the knowledge of the world as his own possession, and thus to rule the power of the fire. Adam also overreached and fell, going to sleep as one and awaking as two, as male and female. As a result of these acts of possessiveness, pride, and loss of consciousness, the fire and the light were separated and came to be at war with one another. Lucifer then knew the fire as hell, as the agonizing Wrath of God.

Human beings also become subject to divine wrath, the fire within, though they may not be aware of it as such during their lifetimes. The human being in the fallen world experiences the fire as intense desires for physical things, for prestige, power, and other vanities. He is like the prodigal son who abandoned his wealthy and loving father and, starving in a far country, tried to fill his belly with the husks meant for the pigs. He does not know that he still also has the light hidden within, that God longs for his return.

On fire with love, God mercifully provided a way for this return. Christ came into the world as a full manifestation of the light of love; he brought the Tinctur, an alchemical concept of a transforming substance. The Tinctur is the fire as transforming power, which is able to change the fire-as-wrath into the fire-as-love. By his suffering and death Christ broke the power of the physical world that imprisoned the human soul (Boehme, 1978, pp. 238, 248).

These means of salvation come home to the soul when he awakens from his sleep and sin and finds that Sophia has come to his door, knocking for admission and offering to be reunited with him in love. The soul admits her with joyful amazement and experiences her marvelous kiss. The soul and Sophia are betrothed-note that the Betrothal happened at the beginning of the spiritual life with Boehme, in contrast to Juan's idea that it happened near the end-but she does not offer the ultimate fulfillment of marriage yet. She withdraws and leaves the soul to live by faith until the appointed time.

The returning soul has to go the hard way of repentance, of total resignation to the will of God, of learning to detach himself from desire for all physical things and other vanities. The fire of human desire now focuses rather on Sophia as the face of God. The soul looks for the day of marriage with Sophia after this life, when she will give him the ultimate gift of bliss, the Pearl of Great Price (Boehme, 1978, pp. 56-62). Beside the individual consummation, an ultimate consummation of the world will take place, in which all things will be revealed. 


\section{Integration}

Here we have three examples of one-world views that unite traditional Christian ideas of salvation with conceptions of the Ultimate, as intimately linked to the basic imagery that appears repeatedly in both mystical and near-death experiences: the void, the fire, and the light. For both Juan and Boehme, the void was not ultimate meaninglessness, but the Divine as seen, so to speak, from the back. Likewise, rather than the fire and the light being irreconcilable hell and heaven, they were presented as integral to the nature of things, as necessarily experienced at different stages in the spiritual journey that climaxed in the ultimate union with the light, or, for Boehme, in the coincidence of fire and light as perfect love.

Boehme also in effect brought the fire down to everyday life, showing that it was what underlay the intense desire for physical things and other vanities that prevails among unawakened souls, and the frustration of which leads to violence. Fox also linked desire for gain with violence, although he did not use the fire image in this connection. Our three mystics, like virtually all other mystics and most NDErs, stressed the importance of essential detachment from such goods and from dependent relationships; true earth-life derives its energy from the Divine within.

One need not necessarily be committed to the Christian scenario that was part of their world-though it is well to be aware that Christian spirituality does possess such resources-to find their musings richly suggestive. One possibility would be to unite some such one-world interpretation of distressing NDEs with an affirmation of the varyingly real existence of the spirit-figures, both the loving and the malevolent, of NDE welcoming committees. Such a position can be consonant with the view that the human consciousness has a part in creating what it sees in such states. I find helpful the persona theory of parapsychologist Hornell Hart, delineated in his book The Enigma of Survival (1959).

Hart surveyed a variety of evidential spontaneous and mediumistic cases in which communication with spirits of the dead appeared to have taken place. He also considered objections that had been raised, such as the fact that certain mediumistic communicators had proven to be fictitious, and the fact that some apparitions had been of persons who were still alive. He proposed that an intelligence that had survived death may have cooperated with the unconscious minds of a medium and with his or her sitters (clients) to create a persona, 
a dramatized entity who was telepathically sensitive both to the messages the surviving intelligence wished to convey, and to the ideas and presumptions of the living persons involved. Such a theory would help to explain the fact that NDErs sometimes see evidential welcomers, such as persons who have recently died without the NDErs' knowledge, as well as the fact that some visionary figures, such as Betty Eadie's Adam and Eve, though they may have a reality of their own, cannot be taken at face value (Eadie and Taylor, 1992).

In regard to the demonic "welcomers" of distressing NDEs, according to this position they may be ephemeral fictional entities, or they may be self-conscious evil discarnate beings, or something between; but they are labile, and the unconscious influence of the NDEr upon them is extensive. Van Rooy, for example, in his sophisticated analysis of his experience, traced the goat-hoof shape of his demonic intruders to earlier scenes of his life in India, where he examined the hooves of slaughtered goats (N. Van Rooy, personal communication). Further, the perceived demonic beings will gain in substantiality and malevolent energy if the NDEr responds to them with fear and/or hostility; Fox's violent reaction to the "men-eaters" may help to explain why his trance lasted so long.

In such a case it is almost impossible for the spiritually undeveloped NDEr to escape without help from outside, in the form of divine or angelic manifestations-which, again, will be partly shaped by the NDEr. Those who have been schooled in the Buddhist consciousnessas-creator worldview are in a better position to deal with such situations. Margot Grey cited the Indian case of a young man in an altered state similar to a distressing NDE, who had been prepared by a spiritual director to stand fast and show no fear in the face of menacing figures. He was able to do this when threatened by a visionary tiger, and in fact it shrank to the size of a domestic cat and turned away (Grey, 1985).

An alternative approach, based on an affirmation of some demonic beings as partially "real," would be to offer them nonviolent love. I have not heard of any NDEs in which this was tried, nor indeed of any mystical experiences, though St. Isaac the Syrian advocated compassion for demons (Isaac the Syrian, 1989, p. 12). In the major Western religious traditions, the vast majority of those who affirm the reality of evil spirits do not seek their redemption. I have heard of a dream in which it was tried, and the menacing figure turned into a steel butterfly (Anonymous, personal communication); Forhan also used it successfully in his out-of-body experiences (Yram, 1974). 
There is the basic practical difficulty that to express nonviolent love in a situation of intense menace requires advanced spiritual development, while NDEs, as Bush (1993) has pointed out, usually happen to amateurs!

It should be noted that psychotherapists who are members of the Association for Past-Life Research and Therapies do practice something analogous to this. They interpret certain common psychological disorders as due to or related to the presence of unhealthy surviving spirits of the dead who have attached themselves to the clients. The clients are treated by a nonviolent depossession therapy that focuses on making the attached entities aware of their situation and encouraging them to let go, to perceive the presence of deceased loved ones, and to go off with the latter into the light. Unlike the faceless and almost interchangeable entities that Van Dusen found in schizophrenia, these entities have names, personalities, and life stories, and in some cases were related to the clients in life. Therapists using the technique claim a high rate of success. Moody has upon occasion collaborated with members of this group (Fiore, 1987).

In the title of this essay I referred to distressing NDEs as photographic negatives. Most persons who discover the existence of these experiences refer to them spontaneously as negative; Bush and other experiencers who have become aware of their complexity and their potential as means of transformation have repeatedly urged that such condemnatory terms be avoided. My title affirms the substance of this critique and provides, one might say, a Tinctur for the unhappy word. The photographic negative gives the true picture with values reversed, but it is a necessary stage in the coming-into-existence of the final picture. I like to think that Boehme, with his profound concern for the cosmic viewing of one's own image in the process of coming into the Ultimate, would have approved.

\section{References}

A. B. (1991, Autumn). From darkness to light. Newsletter of Seattle LANDS (unpaged). Arberry, A. J. (Ed.). (1955). The Koran interpreted. New York, NY: MacMillan.

Atwater, P. M. H. (1988). Coming back to life: The after-effects of the near-death experience. New York, NY: Dodd, Mead.

Atwater, P. M. H. (1994). Beyond the light: What isn't being said about the near-death experience. New York, NY: Birch Lane Press.

Bache, C. (1994). A perinatal interpretation of frightening near-death experiences: A dialogue with Kenneth Ring. Journal of Near-Death Studies, 13, 25-45.

Boehme, J. (1978). The way to Christ. Mahwah, NJ: Paulist Press. 
Brinkley, D., and Perry, P. (1994). Saved by the light. New York, NY: Villard.

Bush, N. E. (1993, June). Distressing near-death experiences. Paper presented at the 1993 North American Conference of the International Association for Near-Death Studies, St. Louis, MO.

Campbell, J. (1949). The hero with a thousand faces. Princeton, NY: Princeton University Press.

Cressey, Judith. (1994). The near-death experience: Mysticism or madness. Hanover, MA: Christopher.

Delacour, J.-B. (1974). Glimpses of the beyond. New York, NY: Delacorte. (Original work published in 1973 as Aus dem Jenseits zurïck)

Eadie, B., and Taylor, C. (1992). Embraced by the light. Placerville, CA: Gold Leaf Press.

Eliot, T. S. (1952). The complete poems and plays, 1909-1950. Orlando, FL: Harcourt Brace.

Evans-Wentz, W. Y. (Trans.). The Tibetan book of the dead, 3rd ed. London, England: Oxford University Press.

Fiore, E. (1987). The unquiet dead: A psychologist treats spiritual possession. Garden City, NY: Dolphin/Doubleday.

Fox, G. (1952). Journal (J. L. Nickalls, Ed.). New York, NY: Cambridge University Press.

Frye, N. (1976). The secular scripture: A study of the structure of romance. Cambridge, MA: Harvard University Press.

Garfield, C. A. (1979). The dying patient's concern with life after death. In R. Kastenbaum (Ed.), Between life and death (pp. 53-56). New York, NY: Springer.

Grey, M. (1985). Return from death: An exploration of the near-death experience. London, England: Arkana.

Greyson, B. (1990, June). Suicide and the near-death experience. Paper presented at the First International Conference of the International Association for Near-Death Studies, Washington, DC.

Greyson, B., and Bush, N. E. (1992). Distressing near-death experiences. Psychiatry, $55,95-110$.

Griffin, D. R. (1993). Parapsychology and philosophy: A Whiteheadian postmodern perspective. Journal of the American Society for Psychical Research, 87. 217-288.

Hart, H. (1959). The enigma of survival. Springfield, IL: Charles C Thomas.

Isaac the Syrian (1989). On ascetical life. Crestwood, NY: St. Vladimir's Seminary Press.

John of the Cross. (1946). The mystical doctrine of St. John of the Cross (C.H. Steuart and R. Steuart, Eds.). Kansas City, MO: Sheed and Ward.

John of the Cross. (1972). The poems of St. John of the Cross (W. Barnstone, Ed.). New York, NY: New Directions.

Katz, S. T. (1978). Mysticism and philosophical analysis. New York, NY: Oxford University Press.

Katz, S. T. (1983). Mysticism and religious tradition. New York, NY: Oxford University Press.

Miller, A. (1990). For your own good. New York, NY: Farrar, Straus and Giroux.

Moody, R. (1975). Life after life. Covington, GA: Mockingbird Books.

Moody, R. (1977). Reflections on life after life. St. Simon's Island, GA: Mockingbird Books.

Otto, R. (1958). The idea of the holy. New York, NY: Oxford University Press.

Rawlings, M. (1978). Beyond death's door. Nashville, TN: Thomas Nelson.

Ring, K. (1994). Solving the riddle of frightening near-death experiences. Journal of Near-Death Studies, 13, 5-23.

Ritchie, G. (1991). My life after dying. Norfolk, VA: Hampton Roads.

Ritchie, G., and Sherrill, E. (1978). Return from tomorrow. Waco, TX: Chosen Books. 
Storm, H. (1989, June). Christian theological interpretations of the near-death experience. Paper presented at the First Annual Conference of the International Association for Near-Death Studies, Rosemont, PA.

Stoudt, J. J. (1968). Jacob Boehme: His life and thought. Long Island City, NY: Seaburn.

Teresa of Avila. (1957). The life of Saint Teresa. Harmondsworth, Middlesex: Penguin. (Original work published 1562)

Tolkien, J. R. R. (1974). The lord of the rings. Boston, MA: Houghton Mifflin.

Underhill, E. (1911). Mysticism. London, England: Methuen.

Van Dusen, W. (1974). The presence of other worlds. New York, NY: Harper and Row. Williams, O. (Ed.). (1952). Immortal poems. New York, NY: Pocket Books.

Yram [Forhan, Marcel Louis]. (1974). Practical astral projection. New York, NY: Samuel Weiser. (Original work published in 1926 as Le medicin de l'ame)

Zaleski, C. (1987). Otherworld journeys: Accounts of near-death experience from medieval and modern times. New York, NY: Oxford University Press. 